\title{
Template Selection during Manipulation of Complex Mixtures by PCR
}

\author{
BioTechniques 30:868-877 (April 2001)
}

D.H.-F. Teng, F. Hsu, I. Peterson, K.E. Cardon, G. Caponigro, and A. Kamb

Arcaris, Salt Lake City, UT, USA

\section{INTRODUCTION}

PCR is a fundamental tool in molecular biology and has played a pivotal role in the reemergence of mammalian somatic cell genetics. It is used widely to construct and manipulate DNA and cDNA libraries. In the context of genetic selections using expression libraries that encode transdominant agents (www.sciencemag.org/cgi/content/full/ $285 / 5426 / 299$ a) $(1,4,6,7,11,14)$, PCR is potentially of great benefit. In principle, a single sequence is sufficient for recovery by amplification.

In many experiments with DNA libraries, the goal is to begin with libraries of maximum diversity (e.g., $10^{7}$ clones), and to isolate the few individual clones that encode transdominant agents active in a particular phenotypic assay. A variety of methodologies have been employed to accomplish the different steps of transdominant genetics in mammalian cells. These steps consist of ( $i$ ) library construction, (ii) gene transfer, (iii) selection, and (iv) recovery. If the initial selection fails to provide sufficient enrichment, then a series of selection cycles may be used, yielding, in principle, a multiplicative enrichment for the overall process.

For recovery and cycling, there are several possible techniques that may be used; for example, PCR followed by cloning or retroviral packaging (17), rescue of transduced mRNA by viral superinfection $(5,15)$, or lox/CRE recom bination and direct $E$. coli transformation using the MaRX shuttle vector system (8). All of these methods could potentially suffer from drawbacks related to the loss of diversity in the library and, a related issue, artifactual skewing of the representation of individual sequences in the library. In PCR, these problems may be considered more serious because of the amplification process. For instance, a loss of population diversity might occur in the first rounds of amplification because of random dropouts of individual template species, which we refer to as template selection.

In this study, we investigate PCR in the context of diversity loss through template selection. The issues explored are also important in the general context of library construction using PCR. The evidence suggests that PCR is a comparatively effective method for library amplification and recovery from cells.

\section{MATERIALS AND METHODS}

\section{PCR Templates and Amplification}

Liver cDNAs were cloned into the pBABE [supplied by Dr. Nikunj Somia (University of Minnesota) and Dr. Inder Verma (Salk Institute)] retroviral vector. Six randomly selected cDNA clones (C1-C6; insert sizes $0.5-2.0 \mathrm{~kb}$ ) were isolated and sequenced. A sub-library of approximately 1000 randomly selected clones was made. We ascertained that it did not contain any of the C1-C6 clones by PCR, using cDNA sequence-specific primer pairs. Plasmid DNAs C1-C6 were mixed with the 
Table 1. Theoretical Cycle Numbers (N) for Producing $100 \mathrm{ng}$ of a 500-bp Fragment with 10000 Input Copies by Model I or II

\begin{tabular}{|llllllll|}
\hline & $\alpha$ & 1.5 & 1.6 & 1.7 & 1.8 & 1.9 & 2.0 \\
\hline Model I & $\mathrm{N}$ & 30 & 26 & 25 & 21 & 19 & 18 \\
Model II & $\mathrm{N}$ & 53 & 46 & 40 & 36 & 33 & 31 \\
\hline
\end{tabular}

sub-library of cDNA plasmids at molar ratios varying from $1: 1000$ to 1 : 100000 . Two picograms (approximately 200000 copies) of these mixtures of cDNA plasmids were reconstituted with $1 \mu \mathrm{g}$ (approximately 150000 genomes) mouse genomic DNA. All DNA quantitation was obtained by spectrophotometric measurement of absorbance at $260 \mathrm{~nm}$ and verified by ethidium-stained gels. Quantitation DNA mass ladder and 100-bp DNA ladder were procured from Life Technologies (Rockville, MD, USA).

In general, amplification reactions contained $20 \mathrm{mM}$ Tris- $\mathrm{Cl}, \mathrm{pH}$ 9.0, 10 $\mathrm{mM} \mathrm{NaCl}, 10 \mathrm{mM} \mathrm{KCl}, 10 \mathrm{mM}$ $\left(\mathrm{NH}_{4}\right)_{2} \mathrm{~S} \mathrm{O}_{4}, 2 \mathrm{mM} \mathrm{MgSO}, 0.1 \%$ Triton ${ }^{\circledR} \mathrm{X}-100,0.2 \mathrm{mM}$ dNTPs, $1 \mu \mathrm{M}$ primers, $1 \mu \mathrm{g}$ template DNA, and 0.05 $\mathrm{U} / \mu \mathrm{L}$ DNA polymerase. Reactions were performed using either Platinum ${ }^{\circledR}$ Taq DNA polymerase (Life Technologies), or AmpliTaq ${ }^{\circledR}$ polymerase (Applied Biosystems, Foster City, CA, USA). When Platinum Taq DNA polymerase was used, thermocycling was preceded by an initial step of $95^{\circ} \mathrm{C}$ for $3 \mathrm{~min}$ to activate the enzyme. When fluorescent PCR products were desired for GeneScan ${ }^{\circledR}$ analyses, reactions containing $0.2 \mathrm{mM}$ unlabeled dNTPs were spiked with $1 \mu \mathrm{M}$ fluorescent R110 dUTP nucleotides (Applied Biosystems).

For the results shown in Table 2A, the mixtures of cDNA templates were reconstituted in vitro at a 1:1 molar ratio with genomic DNA. The reconstituted templates were then subjected to two rounds of hot-start PCR: an initial round of 20 cycles (PCR A), using a primer pair designed to amplify all of the cDNA inserts present among the plasmids, followed by the dilution of the amplified material and a second round of 40 cycles (PCR B), using a primer pair specific to the cDNAs of interest and diluted product from PCR A as template.
For the results presented in Table 2B, the six cDNA clones (C1-C6) were added at 20 molecules (about $0.2 \mathrm{fg}$ for a $10-\mathrm{kb}$ plasmid), 6 molecules (about $0.06 \mathrm{fg}$ ) or 2 molecules (about $0.02 \mathrm{fg}$ ), each to a background mixture of 200000 molecules (about 2 pg) of the sub-library with $1 \mu \mathrm{g}$ mouse genomic DNA and subjected to 20 cycles of am plification (PCR A). The PCR A products were then diluted from 200- to 500fold into PCR B that contained two pairs of primers, one pair specific for the $\mathrm{C} 1$ cDNA clone and another pair specific for C2, C3, C4, C5, or C6. These duplex PCR B were spiked with fluorescent dUTP nucleotides, cycled 30 times, and analyzed using GeneScan.

All PCR As were subjected to cycle titration analyses to ensure that product formation had not plateaued (i.e., amplification was still occurring at the cycle examined).

\section{RESULTS}

The issue of population diversity in DNA libraries is extremely important, particularly in situations when limiting numbers of molecules are available as input (e.g., during recovery of DNA libraries in "negative" selections for sequences that kill or arrest cells, or selections with primary cells of finite life span). In such cases, oversampling is either difficult or impossible. Given that PCR experiments have a threshold for amplification (i.e., a minimum number of templates required to achieve reliable amplification), what are the consequences of such a threshold for the diversity of populations am plified from complex mixtures? The first cycle is the most important one in determining what fraction of the input templates ultimately gives rise to progeny in the amplified product. Any tem- 
plate that fails to replicate in the first few rounds will not be represented among the final products of the PCR. The standard theoretical treatments of PCR do not consider this issue.

In principle, there are two extreme models for computing the number of templates effectively amplified during a PCR (i.e., the diversity): the threshold model (Model I) and the input-fraction model (Model II) (Figure 1). Model I presupposes a threshold of template copies that one must cross to achieve reliable amplification; all templates above this threshold are substrates for amplification. This scenario may apply, for example, if some element in the reaction (such as the tube plastic) binds to a fixed amount of template, preventing its amplification. Model II posits that a constant fraction of input copies functions as templates for amplification. This model is analogous to a first-order (or pseudo-first-order) chemical reaction mechanism in which each template has a constant probability of replicating. Hybrid models in which both scenarios apply to different degrees during the amplification process are also possibilities. A useful model must account for the likelihood that a specific input tem plate in a diverse population of tem plates gives rise to progeny copies in the final amplified mixture. The extreme scenarios (Models I and II) can be described in simple mathematical terms:

Ia. $\mathrm{C}_{\mathrm{N}}=\mathrm{G}+\left(\mathrm{C}_{0}-\mathrm{G}_{\mathrm{T}}\right) \alpha^{\mathrm{N}}$ and

IIa. $\mathrm{C}_{\mathrm{N}}=\mathrm{C}_{0}-\left(\mathrm{C}_{0} / \mathrm{C}_{\mathrm{I}}\right)+\left(\mathrm{C}_{0} / \mathrm{G}_{\mathrm{T}}\right) \alpha^{\mathrm{N}}$, where $\mathrm{N}=$ cycle no.,

$\mathrm{C}_{\mathrm{N}}=$ no. of templates after $\mathrm{N}$ cycles

$\mathrm{C}_{0}=$ no. of input templates

(prior to amplification),

$\mathrm{C}_{\mathrm{I}}=$ no. of ineffective templates (approximately the minimum number of templates necessary to obtain product), $\alpha=$ mean amplification efficiency [ $1<$

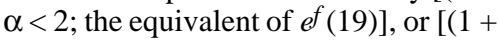
$\left.\left.E^{\mathrm{T}}\right)(15)\right]$.

At the minimum number of templates necessary to achieve amplification,

\section{Ib. $1=\mathrm{C}_{0}-\mathrm{G}$,}

IIb. $1=\mathrm{G} / \mathrm{G}$.

Thus, for both cases $\mathrm{C}_{0}$ approximately equals $\mathrm{C}_{\mathrm{I}}$. This allows estimation of $\mathrm{C}_{\mathrm{I}}$ from the experiment. For $\mathrm{C}_{0}$ much greater than $\mathrm{C}_{\mathrm{I}}$, the equations for the two cases reduce to:

Ic. $\mathrm{C}_{\mathrm{N}}=\mathrm{C}_{0} \alpha^{\mathrm{N}}$ [the fundamental

expression for PCR if $\alpha=2$; (18)]

IIc. $\mathrm{C}_{\mathrm{N}}=(\mathrm{C} / \mathrm{G}) \alpha^{\mathrm{N}}$.

Therefore, it is a simple matter to measure $\mathrm{C}_{\mathrm{I}}$ (typically measured between 10 and 10000 , depending on primers, template quality, and enzyme used) and $\alpha$ (typically estimated to fall between 1.5 and 2.0, depending on the conditions and the cycle number used in the computation) and to compare the two cases to determine which one better represents the relationship between the cycle number and amplified material, given the known amounts of input template (Teng, unpublished results) (13). Note that the sensitivity of PCR amplification, a measure of which is $\mathrm{C}_{\mathrm{I}}$ (the minimum number of templates required to obtain a product), is not especially relevant in Model I (within reasonable limits), but is critical in Model II.

We designed an experiment to test the predictions of these disparate models. Two specific plasmid templates $(\mathrm{C} 1$

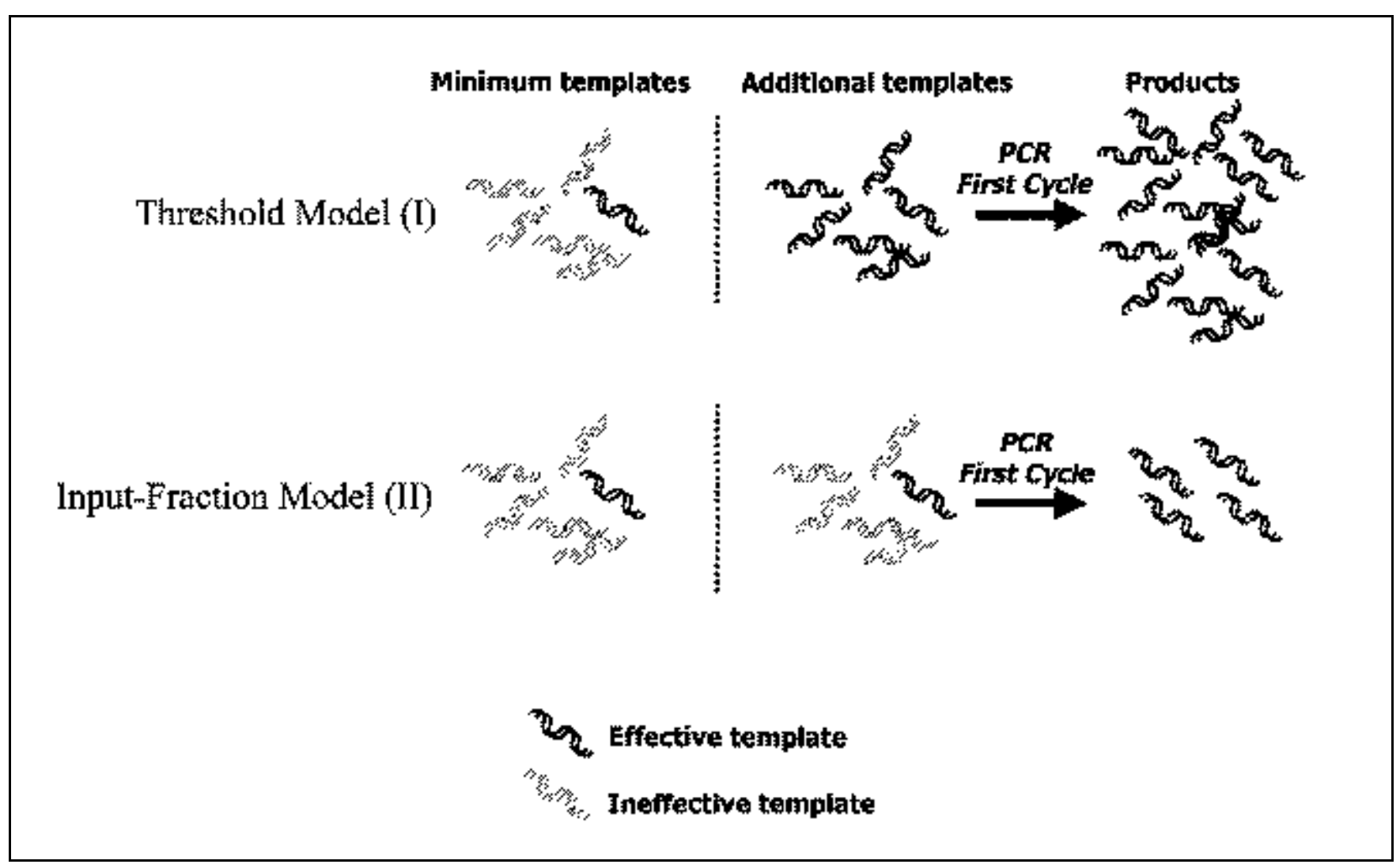

Figure 1. Cartoon illustrating template selection under Models I and II. $C_{I}$, the number of ineffective templates in the initial step of PCR (five, in this case) is the same for both models. The "minimum templates" refer to the smallest number of copies required to achieve amplification (approximately G). 


\section{Research Report}

and $\mathrm{C} 2$ ) were mixed at $1: 1$ ratios with genome-equivalent masses of genomic DNA to mimic the effect of single-copy sequences amplified from genomic DNA (e.g., transduced retroviral inserts). The templates were amplified separately at various dilutions using AmpliTaq DNA polymerase, and the reactions were analyzed after certain cycle numbers. The cycle number at which $100 \mathrm{ng}$ amplified material appeared was estimated $\left(\mathrm{C}_{\mathrm{N}}=2 \times 10^{11}\right)$ for a defined amount of input template (e.g., $\mathrm{C}_{0}=10^{6}$ ). The sensitivity of these amplifications $\left(\mathrm{C}_{\mathrm{I}}\right)$ was measured as approximately $10^{4}$ input copies. The cycle number $(\mathrm{N})$ was calculated according to the two scenarios for values of $\alpha$ (am-

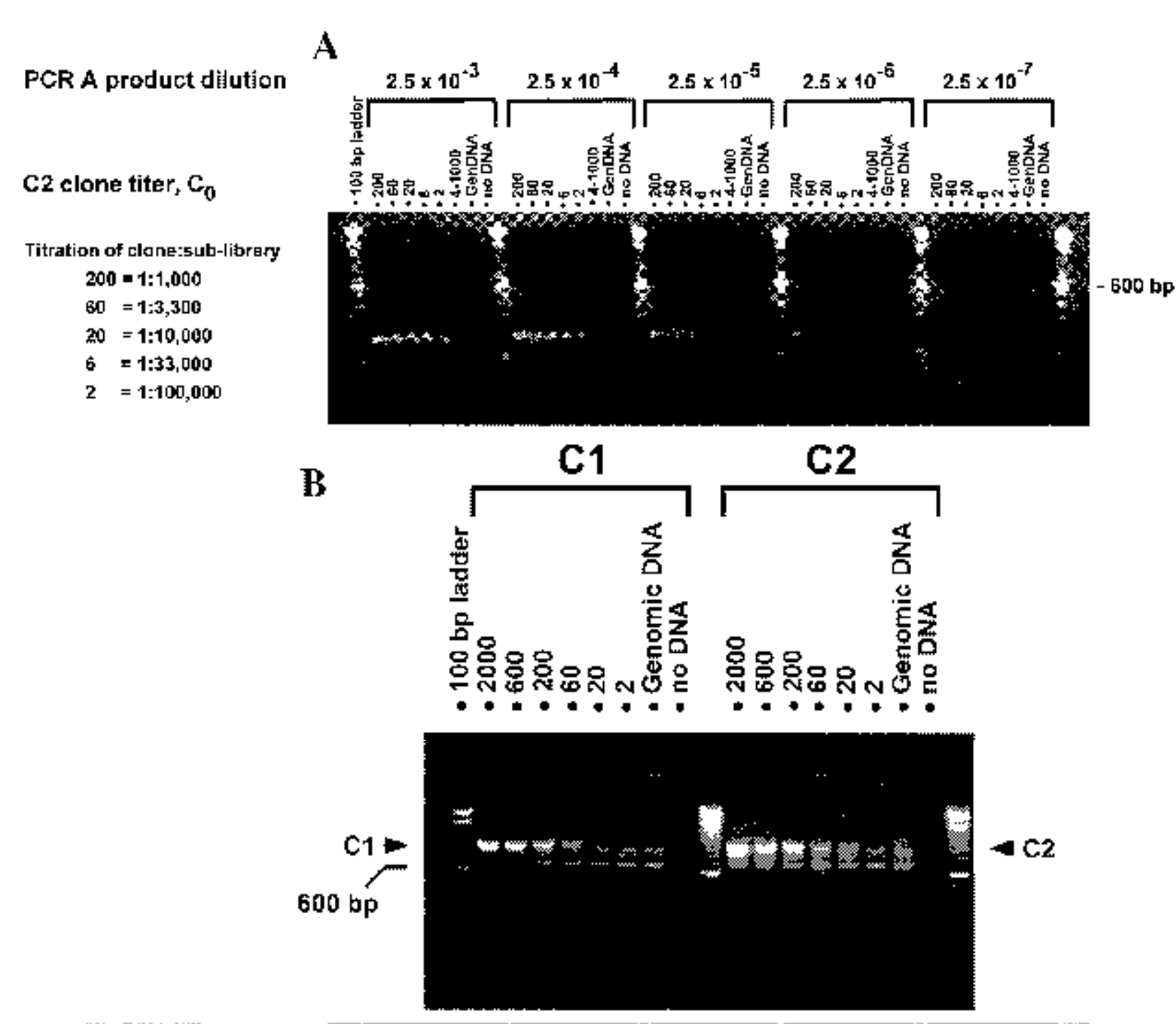

Figure 2. Assessing the recovery of specific sequences by PCR. (A) PCR recovery of specific sequences from a complex DNA mixture. Six randomly selected cDNA plasmids (C1-C6; insert sizes $0.5-2.0 \mathrm{~kb}$ ) were added to a sub-library of cDNA plasmids at molar ratios varying from 1:1000 to 1:100 000, in a background of mouse genomic DNA (see Materials and Methods). This template reconstituted in vitro was subjected to two rounds of PCR amplification. In the first round (PCR A), $1 \mu \mathrm{g}$ template was amplified in a 50- $\mu \mathrm{L}$ reaction with primers that flanked the cloned cDNA inserts and Platinum Taq DNA polymerase (Life Technologies). The reaction was cycled 20 times at $96^{\circ} \mathrm{C}$ for $30 \mathrm{~s}, 60^{\circ} \mathrm{C}$ for $30 \mathrm{~s}$, and $72^{\circ} \mathrm{C}$ for $90 \mathrm{~s}$. The products of PCR A were then serially diluted from 2.5 $\times 10^{-3}$ - to $2.5 \times 10^{-7}$-fold into a secondary reaction (PCR B) containing primer pairs specific for one of the cDNAs $\left(\mathrm{G}, \mathrm{C}_{2}\right.$, or $\left.\mathrm{C}_{3}\right)$, and then the reactions were cycled 40 times at $96^{\circ} \mathrm{C}$ for $30 \mathrm{~s}, 60^{\circ} \mathrm{C}$ for $30 \mathrm{~s}$, and $72^{\circ} \mathrm{C}$ for $30 \mathrm{~s}$. Twenty microliters each PCR B sample was fractionated by agarose gel electrophoresis and visualized by ethidium bromide staining. Altogether, two independent dilution series of templates for PCR A were made, and three independent data points were obtained for each template series. The PCR B data for one of the cDNAs, C2, is shown as a representative result. (B) Determining G for hot-start PCR. Specific cDNA plasmids (C1-C6) were serially diluted from 2000 copies down to two copies, into $1 \mu$ g mouse genomic DNA (approximately 150000 genomes). One of each template mixture was used in a 50- $\mu \mathrm{L}$ reaction containing a primer pair flanking the cloned cDNA inserts and Platinum Taq DNA polymerase. The enzyme was activated with an initial step of $95^{\circ} \mathrm{C}$ for $3 \mathrm{~min}$. The reactions were then thermocycled 40 times at $96^{\circ} \mathrm{C}$ for $30 \mathrm{~s}, 60^{\circ} \mathrm{C}$ for $30 \mathrm{~s}$, and $72^{\circ} \mathrm{C}$ for $90 \mathrm{~s}$. Twenty microliters PCR products were fractionated by agarose gel electrophoresis and visualized by ethidium bromide staining. The $\mathrm{G}$ and $\mathrm{G}$ clones shown had cDNA fragments of approximately 900 and $850 \mathrm{bp}$, respectively. 


\section{Research Report}

Table 2A. Agarose Gel Analysis of Amplification Products from PCR B

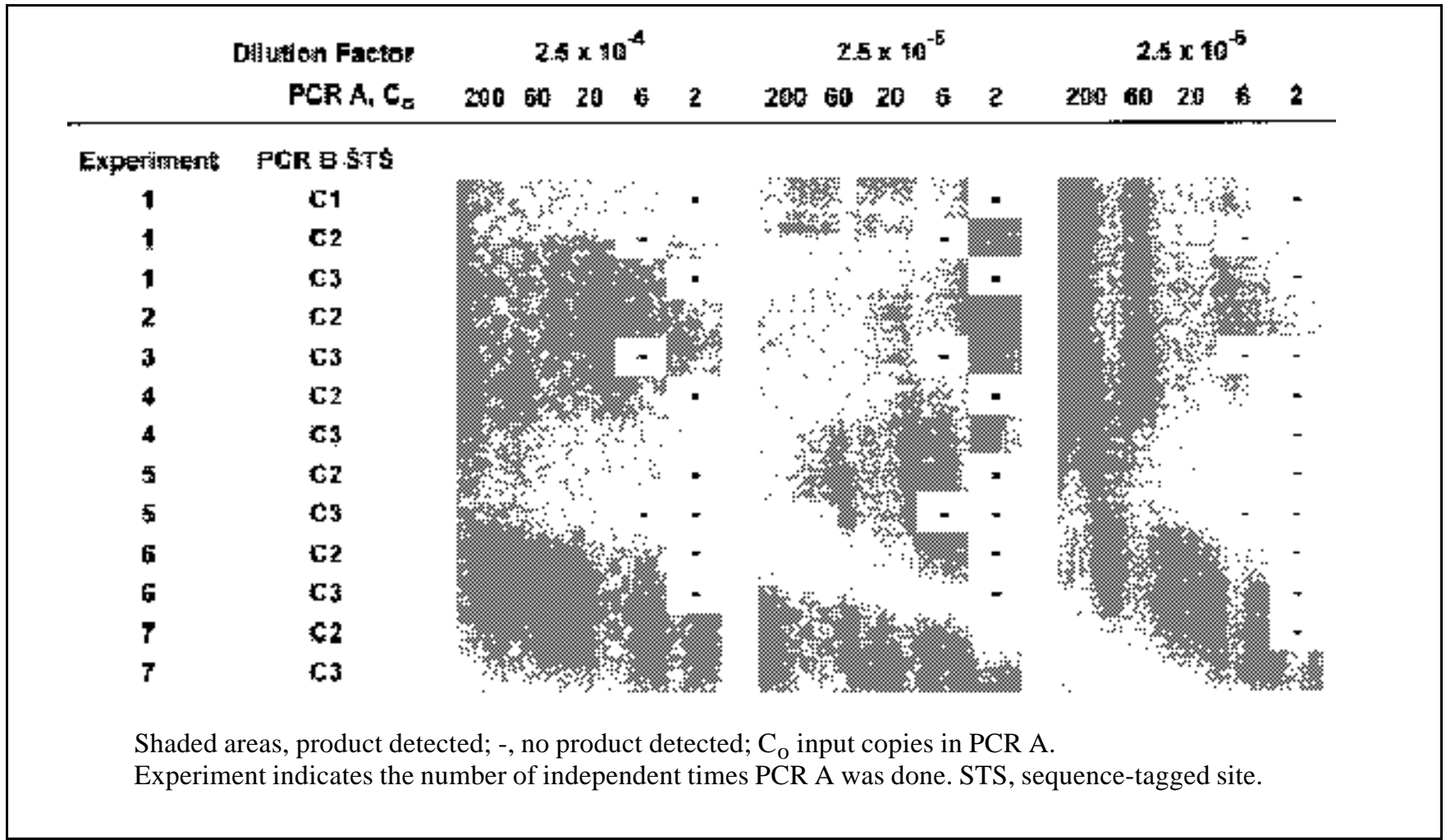

plification efficiency), ranging from 1.5 to 2.0, and compared with the measured value from the experiment (Table 1). In two independent experiments using the two templates, $100 \mathrm{ng}$ of product was visible between cycles 25 and 30 , in much closer agreement with Model I.

An independent line of experiments also supported Model I. The first part of the experiment involved PCR with reconstituted templates (PCR A) consisting of specific cDNAs mixed with a sub-library of 1000 other cDNAs at defined ratios ranging from $1: 1000$ to 100000 . The second part of the experiment consisted of the dilution of the PCR A product into another PCR (PCR $\mathrm{B})$, by which the effective presence or absence of specific sequences was examined. The failure to detect doped sequences by PCR B was interpreted as the absence of specific amplified material among the products of PCR A. As an example of representative data for one cDNA mixture, approximately 20 molecules of $\mathrm{C} 2$ were mixed with a total of 200000 sub-library templates (i.e., 1:10000). If the PCR was perfectly efficient $(\alpha=2)$, one would generate roughly $2 \times 10^{7}$ molecules of the $\mathrm{C} 2$ in- sert after 20 cycles of PCR A. Follow ing dilution by a factor of $2.5 \times 10^{-6}$, a positive result (i.e., detectable amplification) was obtained in all six independent PCR B for each of the three $\mathrm{cD}$ NAs examined (Figure 2A). The sensitivity $\left(\mathrm{C}_{\mathrm{I}}\right)$ was measured as approximately 60 copies for PCR A (Figure $2 \mathrm{~B}$ ) and somewhat higher (approximately 10 copies) for PCR B (Table 2). This difference could have been caused by the primers, by the amplified tem plate used for PCR B, or by both. For the set of reactions, the incidence of failure and success was tabulated (Table 2A).

A similar series of experiments was performed with a higher-resolution method that permits the analysis of the amplification of two templates simultaneously. The detection of PCR B products using fluorescent labels, polyacrylamide gels, and GeneScan software revealed an all-or-nothing behavior that confirmed the agarose gel results (Table 2B). The detection of at least one of the two duplex reaction products demonstrated that dropouts of individual rare sequences were not caused by poor PCR that failed to amplify all of 


\section{Research Report}

Table 2B. GeneScan Analysis of Duplex PCR B

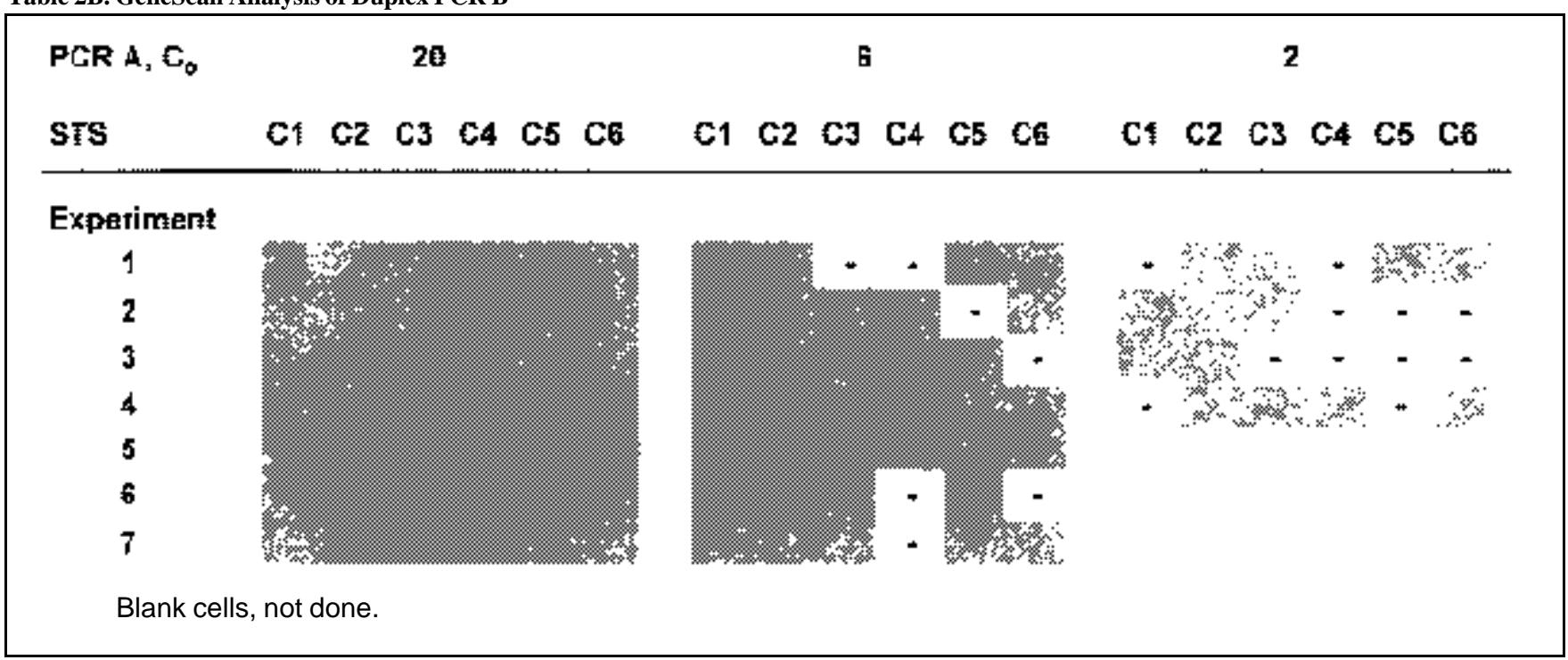

Table 2C. Summary of PCR B Data

\begin{tabular}{|c|c|c|c|c|c|}
\hline $\begin{array}{c}\mathrm{C}_{0} \\
\text { (Model I) }\end{array}$ & $\begin{array}{c}\mathrm{C}_{0} / \mathrm{C}^{\mathrm{a}} \\
\text { (Model II) }\end{array}$ & $\mathrm{C}_{0}$ (Est. $^{\mathrm{b}}$ & $\begin{array}{c}\text { Amplified/ } \\
\text { Total \% }\end{array}$ & Model I\% (Calc.) & Model II\% (Calc.) \\
\hline 20 & 0.3 & $>3$ & $100 \%(55 / 55)$ & $100 \%$ & $28 \%$ \\
\hline 6 & 0.1 & 1.7 & $82 \%(45 / 55)$ & $>99 \%$ & $10 \%$ \\
\hline 2 & 0.03 & 0.8 & $54 \%(20 / 37)$ & $86 \%$ & $3 \%$ \\
\hline
\end{tabular}

the templates. The combined results of these analyses are summarized in Table 2C. Compared to the success rates for amplification predicted by Model I (calculated), the observed results were identical for 20 copies (100\%), approximately $80 \%$ for six copies, and approximately $60 \%$ for two copies. Using Model II as a predictor, the agreement was much worse: 4-fold higher for 20 copies, 8-fold higher for six copies, and 18-fold higher for two copies.

\section{DISCUSSION}

PCR is used in numerous situations and has acquired a reputation for robustness. In many applications of PCR, such as library construction, library amplification and recloning, and hybrid selection, the amplification of complex mixtures of DNA sequences is required. In these cases, PCR has been employed with qualitatively favorable outcomes $(9,12)$. One of the more interesting types of application in this regard involves transdominant genetics in mammalian cells. In this context, it is critical to recover DNA expression libraries from cultured cells, often at minimal redundancy.

There are two major concerns about PCR in the context of library amplification and recloning: loss of diversity caused by template selection and sequence skewing. In this study, we examined the behavior of PCR with respect to the loss of diversity caused by template selection in reconstituted systems. We subjected PCR to a variety of tests and showed that it is a comparatively effective method for maintaining diversity in complex DNA mixtures.
Data in Table 1 revealed that, overall, replication of specific sequences in a complex DNA mixture by PCR approximates the threshold model (Model I). However, the amplification failure rates did not match perfectly with this model's predictions. The estimated copy numbers determined from observed failure rates were about 3 -fold lower than the input quantities (Table 2C). This finding may suggest that this model is an oversimplification of the process of template selection during PCR, although it is a much better approximation than the input-fraction model, Model II (Table 2C).

The issue of sequence skewing during PCR has been addressed in several studies $(10,15,16,19)$. For example, Suzuki and Giovannoni (19) observed normalization pressure during mixed template PCR at high template concen- 
trations. It is likely that occasional specific sequences are not amplified efficiently from DNA libraries for several reasons, including GC content and length. To a certain extent, such problems may be minimized by choosing longer extension times to give longer fragments sufficient time to complete replication and by using complex mixtures in which individual sequences are present at low concentration (19). In the context of very large cDNA fragments, non-PCR-based methods may have an advantage, although we have recovered $2.5 \mathrm{~kb}$ fragments from selections using PCR (A. Kamb, unpublished). PCR becomes less reliable as fragment sizes exceed $3 \mathrm{~kb}(2,3)$. How ever, alternative plasmid rescue methods may also suffer because of the decrease in transformation frequency as plasmids increase in size. It is also worth noting that transdominant experiments using random peptide libraries with inserts of homogeneous size may suffer minimal skewing because of the typical short length ( $<100 \mathrm{bp}$ ), the high diversities (and the subsequent low concentrations of individual sequences), and the identical sizes of the inserts.

In summary, PCR is an effective tool for amplification of complex sequence mixtures, particularly when sequences are neither too long nor too heterogeneous in length. PCR follows a threshold model rather than an input-fraction model. The template selection during PCR amplification preserves a large fraction of sequences from mixtures of non-redundant input DNAs. If minimal levels of redundancy can be achieved (e.g., 3-fold), it should be possible to maintain high levels of input sequence diversity using PCR.

\section{ACKNOWLEDGMENTS}

The $\mathrm{pBABE}$ and $\mathrm{pMFG}$ retroviral expression vectors were kindly provided by Dr. Nikunj Somia and Dr. Inder Verma. We are grateful to Chunwei Wang for assistance with computer sequence analysis, and Rex Malmstrom for technical assistance, and Dr. Jon Karpilow, Karen Repetny, Dr. Burt Richards, and Dr. Ken McCormack for construction of cDNA libraries.

\section{REFERENCES}

1.Caponigro, G., M.R. Abedi, A.P. Hurlburt, A. Maxfield, W. Judd, and A. Kamb. 1998. Transdominant genetic analysis of a growth control pathway. Proc. Natl. Acad. Sci. USA 95:7508-7513.

2.Cheng, S., S.Y. Chang, P. Gravitt, and R. Respess. 1994. Long PCR. Nature 369:684685.

3.Cohen, J. 1994. "Long PCR" leaps into larger DNA sequences. Science 263:1564-1565.

4.Dunn, S.J., S.W. Park, V. Sharma, G. Raghu, J.M. Simone, R. Tavassoli, L.M. Young, M.A. Ortega et al. 1999. Isolation of efficient antivirals: genetic suppressor elements against HIV-1. Gene Ther. 6:130-137.

5.Gallagher, W.M., M. Cairney, B. Schott, I.B. Roninson, and R. Brown. 1997. Identification of p53 genetic suppressor elements which confer resistance to cisplatin. Oncogene 14:185-193.

6.Geyer, C.R., A. Colman-Lerner, and R. Brent. 1999. "Mutagenesis" by peptide aptamers identifies genetic network members and pathway connections. Proc. Natl. Acad. Sci. USA 96:8567-8572.

7.Gudkov, A.V. and I.B. Roninson. 1997. Isolation of genetic suppressor elements (GSEs) from random fragment cDNA libraries in retroviral vectors. Methods Mol. Biol. 69:221240.

8.Hannon, G.J., P. Sun, A. Carnero, L.Y. Xie, R. Maestro, D.S. Conklin, and D. Beach. 1999. MaRX: an approach to genetics in mammalian cells. Science 283:1129-1130.

9.Hattier, T., R. Bell, D. Shaffer, S. Stone, R.S. Phelps, S.V. Tavtigian, M.H. Skolnick, D. Shattuck-Eidens et al. 1995. Monitoring the efficacy of hybrid selection during positional cloning: the search for BRCA1. Mamm. Genome 6:873-879.

10.Higuchi, R., C. Fockler, G. Dolligner, and R. Watson. 1993. Kinetic PCR analysis: realtime monitoring of DNA amplification reactions. Biotechnology 11:1026-1030.

11.Holzmayer, T.A., D.G. Pestov, and I.B. Roninson. 1992. Isolation of dominant negative mutants and inhibitory antisense RNA sequences by expression selection of random DNA fragments. Nucleic Acids Res. 20:711717.

12.McCarrey, J.R. and S.A. Williams. 1994. Construction of cDNA libraries from limiting amounts of material. Curr. Opin. Biotechnol. 5:34-39.

13.Morrison, C. and F. Gannon. 1994. The im pact of the PCR plateau phase on quantitative PCR. Biochim. Biophys. Acta 1219:493-498.

14.Norman, T.C., D.L. Smith, P.K. Sorger, B.L. Drees, S.M. O'Rourke, T.R. Hughes, C.J. Roberts, S.H. Friend et al. 1999. Genetic selection of peptide inhibitors of biological pathways. Science 285:591-595.

15.Raeymaekers, L. 1993. Quantitative PCR: theoretical considerations with practical im plications. Anal. Biochem. 214:582-585.

16. Raeymaekers, L. 1995. A commentary on the practical applications of quantitative PCR. Genome Res. 5:91-94.

17.Schott, B., E.S. Iraj, and I.B. Roninson. 1997. Efficient recovery and regeneration of integrated retroviruses. Nucleic Acids Res. 25:2940-2942.

18.Saiki, R.K, S. Scharf, F. Faloona, K.B. Mullis, G.T. Horn, H.A. Erlich, and N. Arnheim. 1985. Enzymatic amplification of betaglobin genomic sequences and restriction site analysis for diagnosis of sickle cell anemia. Science 230:1350-1354.

19.Suzuki, M.T. and S.J. Giovannoni. 1996. Bias caused by template annealing in the am plification of mixtures of 16SrRNA genes by PCR. Appl. Environ. Microbiol. 62:625-630.

Received 20 April 2000; accepted 22 November 2000.

Address correspondence to:

Dr. Alexander Kamb

Arcaris

615 Arapeen Drive

Suite 300

Salt Lake City, UT 84108, USA

e-mail:kamb@arcaris.com 